\title{
イオンプレーティング法による 窒化アルミニウム薄膜の作製*
}

岡野 寛*1 増田 知弘 $* 1 \cdot$ 道久 明宏 $* 1 \cdot$ 長谷川弘治 $* 2$

（受理2003年11月 13 日，揭載決定2004年 2 月 14 日）

Preparation of Aluminum Nitride Thin Films

by RF Reactive Ion Plating.

Hiroshi OKANO*1, Tomohiro MASUDA*1, Akihiro MICHIHISA*1 and Koji HASEGAWA*2

\footnotetext{
*1Takamatsu National College of Technology, 355 Chokushi, Takamatsu, Kagawa, 761-8058, Japan

*2Department of Electrical and Electronic Engineering, Muroran Institute of Technology, 27-1 Mizumoto-cho, Muroran, 050-8585, Japan)
}

(Received November 13, 2003, Accepted February 14, 2004)

\begin{abstract}
Aluminum nitride (AIN) thin films are very promising materials for piezoelectric devices. It is found from computed results that the layered structure, c-axis oriented $\mathrm{AlN}$ thin film on $\mathrm{SiO}_{2} /(100) \mathrm{Si}$, will exhibit high phase velocity (4760 $\mathrm{m} / \mathrm{s})$ with high coupling coefficient $(0.0075)$, whose value is more than that of quartz $(0.0011)$. AlN thin films were deposited on glass substrate by RF reactive ion plating system. It was confirmed that the transmittance and deposition rate of AlN thin films depend on distance of antenna-substrate greatly. Deposition rate became small when distance of antenna-substrate was enlarged. Transmittance of AlN increases with increasing deposition rate at the deposition rate of less than $0.4 \mathrm{~nm} / \mathrm{s}$.
\end{abstract}

\section{1. はじめに}

携帯電話や無線 LANなどの移動体無線機器で使用さ れる周波数が現在の $2 \mathrm{GHz}$ 帯から $3 \sim 5 \mathrm{GHz}$ 帯へ移行 していくことが予想され，それに対応した無線 RF 部の バンドパスフィルタの開発が必要である. 現在無線 RF 部のバンドパスフィルタには弾性表面波（SAW）フィ ルタが使用されて抢り，また次世代のフィルタとして圧 電薄膜共振子の研究が盛んである ${ }^{1,2)}$. どちらの素子も 高品質な圧電材料を得ることが重要であり, SAWフィ ルタの高周波数化には, 高音速な弾性表面波を伝搬させ

\footnotetext{
* 平成15年11月13日 第44回真空に関する連合講演会で発表

*1 高松工業高等専門学校 (干761-8058 香川県高松市勅使町355番地)

*2 室闌工業大学 電気電子工学科 ( $\overline{\mathbf{T}} 050-8585$ 北海道室蘭市水元町 27 番 1 号)
}

\section{ることが重要である.}

窒化アルミニウム (AIN) は物理的・化学的に非常に 安定であり，また圧電性を有するため，有機 EL 素子な どのパッシベーション膜や各種超音波素子用材料として 有望視されてきた ${ }^{3,4)}$. しかし AlN は SAWの電気機械 結合係数が小さいためSAWフィルタに利用する場合, 電極設計上の課題が多く実用化には至っていない。近年 盛んに研究されている压電薄膜共振子の場合, 求められ る材料特性として, 膜厚変動時の周波数変動を最小限に 抑えるため，バルク波の音速が大きいこと，更にバルク 波の電気機械結合係数が大きいこと, 温度变動時の音速 の変動が小さいこと，などが上げられる11. AlNの場 合，バルク波の音速は $11300 \mathrm{~m} / \mathrm{s}$, 電気機械結合係数は $6.5 \%$, 温度係数は $-25 \mathrm{ppm} /{ }^{\circ} \mathrm{C}$ であり理想的な材料 1 で ある、また, AlN は圧電体の中では最も高音速な SAW 
を伝搬することが可能であるため SAWフィルタ用材料 としても再度検討する価值がある.

$\mathrm{AlN}$ 薄膜の作製は, 各種スパッタ法 ${ }^{5-7)}, \mathrm{CVD}$ 法8,9) 等により報告されている. 今回, SAW デバイスの製造 現場に必ず存在する, 抵抗加熱蒸着装置に, RF アンテ ナ（ループアンテナ）を追加した, 低コストな薄膜形成 手法であるイオンプレーティング法により $\mathrm{AlN}$ 薄膜の 作製を試みた。

イオンプレーティング法により高品位な薄膜を作製す るには, RFパワ一, 反応告力, 基板温度, 基板一蒸着 源間距離等の最適化が必要であると指摘されており多く の研究報告 ${ }^{10)}$ がある.このうち， RFパワ一や基板一蒸 着源間距離はプラズマ中の電磁界分布に大きく影響を与 えており，それが膜質に影響していることが予想され る.しかし，チャンバー内の電磁界分布に影響するアン テナの位置, すなわち誘導結合型プラズマを発生させる 際の RF アンテナと基板との位置関係が膜質に及ぼす影 響についてはあまり報告がない。本論文では主に電磁界 分布に大きく影響を与える RFアンテナと基板, 蒸着源 の位置関係や RFパワーが膜質に与える影響を考察し た.

また同時に, SAWフィルタに応用する際の基本構造 の 1 つである $\mathrm{AlN} / \mathrm{SiO}_{2} / \mathrm{Si}$ 構造における, $\mathrm{SAW}$ 特性を Matix Methodによりシミュレーションし, AIN 薄膜上 の SAW 伝搬特性を試算した.

\section{2. 実験方法}

\subsection{SAW 特性のシミュレーション}

$\mathrm{SiO}_{2} / \mathrm{Si}(100)$ 基板上の $\mathrm{AlN}$ 薄膜の SAW 特性は,

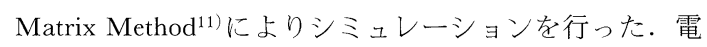
気機械結合係数は, $\mathrm{AlN} / \mathrm{SiO}_{2} /(100) \mathrm{Si}$ 構造の表面をメ タライズした場合と,フリーの場合の SAW の伝搬速度 の差から算出した。 また, 伝搬速度の計算結果として は，表面がフリーな場合の計算結果を示した。

\section{$2.2 \mathrm{AlN}$ 薄膜の作製と評価}

AIN 薄膜は, イオンプレーティング法により作製し た. RF アンテナの位置は基板の位置からの距離を基準 に変化させた，Table 1 に作製条件を示す，基板はア一 又電位とし, 電圧は印加していない.Fig. 1 に装置の概 略図を示す，基板一アンテナ間距離はアンテナの位置を 移動することで $2 \sim 7 \mathrm{~cm}$ の間で変化させた．基板一蒸 着源間の距離は $11 \mathrm{~cm}$ である。 またシャッターの位置は 固定した。

薄膜の組成はオージエ電子分光法, 結晶性は X 線回 折分析により評価した。透過率は，430, 550, $700 \mu \mathrm{m}$ で の測定值を平均した值を使用した。
Table 1 Deposition conditions of aluminam thin films

\begin{tabular}{lc}
\hline \hline Substrate & Cornning 7059 \\
Deposition Source & Aluminum $(99.999 \%)$ \\
Substrate Temperature & Room Temperature \\
Reactive Pressure & $0.1 \sim 0.4 \mathrm{~Pa}$ \\
RF Power & $100 \sim 500 \mathrm{~W}$ \\
$\mathrm{~N}_{2}$ Flow Rate & $3 \sim 5 \mathrm{SCCM}$ \\
Back Pressure & $5 \times 10^{-5} \mathrm{~Pa}$ \\
\hline
\end{tabular}

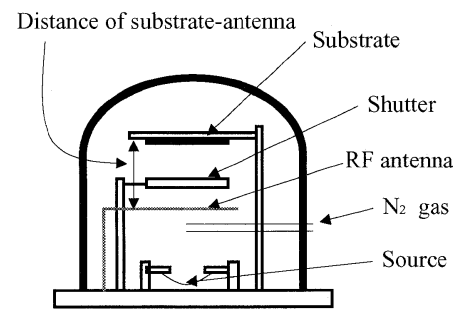

Fig. 1 Apparatus of the ion plating system used in this experiment.

\section{3. 結果及び考察}

\subsection{SAW 特性のシミュレーション}

シミュレーションを行った素子構造は, 基板に(100) $\mathrm{Si}$ を使用し, 中間層として $\mathrm{SiO}_{2}$ を挿入し最上部に $\mathrm{AlN}$ 膜が位置する構成である. AlN の成長方位は一番安定 に再現性良く形成可能な c 面を仮定し, SAW の伝搬方 向は $\mathrm{a}$ 軸方向である. 中間層 $\mathrm{SiO}_{2}$ の相対膜厚を $\mathrm{hSiO}_{2} /$ $\lambda=0,0.1,0.2$ として AlN の相対膜厚と伝搬速度及び電 気機械結合係数の関係をシミュレーションした。

Fig. 2 に伝搬速度，Fig. 3 に電気機械結合係数の計算 結果を示す. $\mathrm{h}_{\mathrm{AIN}} / \lambda$ が0.2以上の場合, $\mathrm{h}_{\mathrm{AIN}} / \lambda$ の増加と

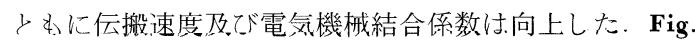
4 K AlN の相対膜厚 $\left(\mathrm{h}_{\mathrm{AIN}} / \lambda\right)$ を0.4に固定した場合の， 中間層 $\mathrm{SiO}_{2}$ の膜厚々音速及び電気機械結合係数の関係 を示す。音速は $\mathrm{Si}$ 基板と $\mathrm{AlN}$ の間に $\mathrm{SiO}_{2}$ 層を挿入す ることにより，10～15\%程度低下（5180 $\rightarrow 4760 \mathrm{~m} / \mathrm{s})$ す るが，電気機械結合係数は， $\mathrm{SiO}_{2}$ 層を挿入することに より，20〜30\%改善 $(0.0050 \rightarrow 0.0075)$ することが分か った。 なた $\mathrm{SiO}_{2}$ の有無にかかわらず電気機械結合係数 は水晶の電気機械結合係数 $(0.0011)^{12)}$ を上回り, AlN 薄膜が SAW フィルタ用材料として十分実用化可能なこ とが分かった。 


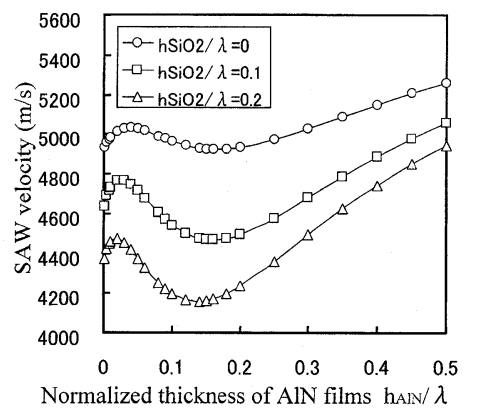

Fig. 2 Computed results of phase velocity for AlN/ $\mathrm{SiO}_{2} /(100) \mathrm{Si}$.

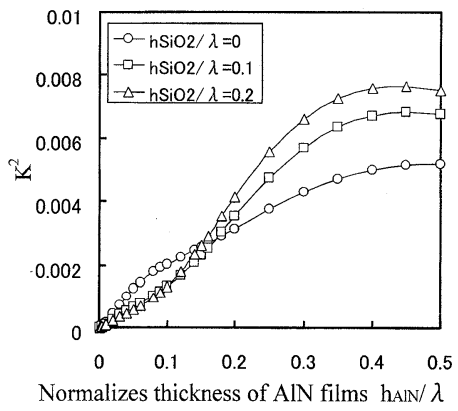

Fig. 3 Computed results of coupling coefficient for $\mathrm{AlN} / \mathrm{SiO}_{2} /(100) \mathrm{Si}$.

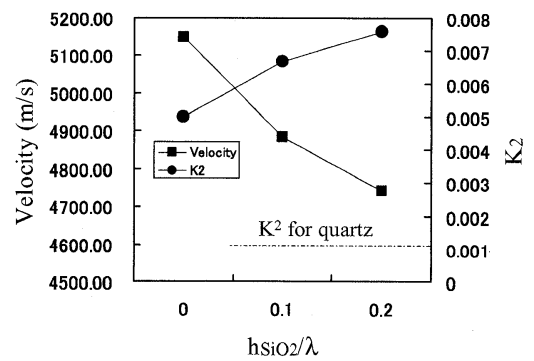

Fig. 4 Computed results of phase velocity and coupling coefficient for $\mathrm{AlN} / \mathrm{SiO}_{2} /(100) \mathrm{Si}$ at $\mathrm{h}_{\mathrm{AlN}} / \lambda$ of 0.4 .

\subsection{AlN 薄膜の作製}

始めに, 窒素ガス雲囲気中で抵抗加熱によりアルミニ ウムを蒸発させ AlNの作製を試みた．Fig. 5 に製膜時 間と膜厚の関係を示す．膜厚は製膜時間に比例し製膜時 間を制御することで膜厚を制御可能なことが分かった。 しかしオージエ電子分光法により，組成分析を行った結 果, 得られた薄膜は純了ルミニウムであり全く窒化して いないことが分かった。

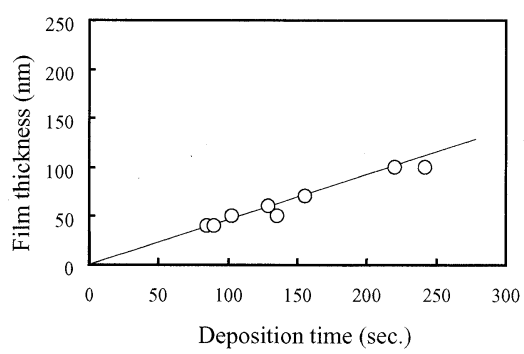

Fig. 5 Relationship between the deposition time and film thickness.

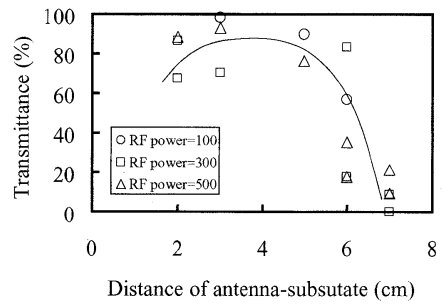

Fig. 6 Dependence of transmittance for AlN thin films on antenna-substrate distance at the RF power of 100,300 and $500 \mathrm{~W}$.

次に, RF (13.56 MHz) 印加による窒素プラズマ中 で AlN 薄膜の作製を試みた．プラズマはループ状アン テナを使用した誘導結合型プラズマである.このような 手法で化合物薄膜を形成する際には RF パワー, 反応圧 力, 基板温度, 基板一蒸着源間距離等が膜質に大きく影 響を与えることが知られている．このうち，RFパワー や基板一蒸着源間距離はプラズマ中の電磁界分布に大き く影響を与えており，それが膜質に影響しているにとが 予想される. 本研究では RF を印加する際の, アンテナ の位置（基板一アンテナ間距離）と RFパワーを変化さ せ AlN 薄膜を作製し膜質, 主に可視光透過率への影響 を検討した。Fig. 6 に RFパワーが 100, 300, 500 Wの 時の基板一アンテナ間距離と可視光透過率の関係を示 す. 透過率は基板一アンテナ間距離に大きく依存し基板 一アンテナ間距離が $3 \sim 5 \mathrm{~cm}$ の時最大となった。 基板 一アンテナ間距離を $5 \mathrm{~cm}$ 以上とすると急激に透過率は 低下した。また，基板一アンテナ間距離を $2 \mathrm{~cm}$ ，すな わちアンテナを基板側に近寄づけても透過率は低下し た。

Fig. 7 に基板一アンテナ間距離を変化させた場合の $\mathrm{RF} ハ ゚ ワ ー と$ 可視光透過率の関係を示す．基板一アンテ 十間距離が $6 \mathrm{~cm}$ 以上の場合，すなわちアンテナを基板 から大きく離し蒸着源に近づけた場合は, 透過率は RF 


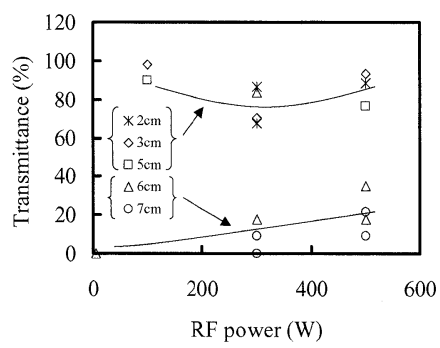

Fig. 7 Dependence of transmittance for AlN thin films on RF power at the defferents antenna-substrate distance.

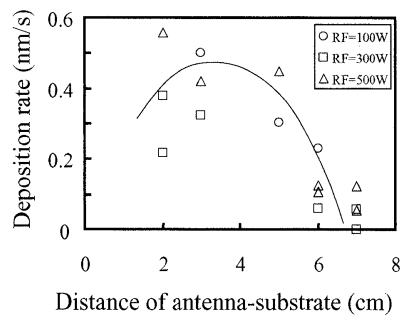

Fig. 8 Dependence of deposition rate for AlN thin films on antenna-substrate distance at the RF power of 100,300 and $500 \mathrm{~W}$.

パワーに依存し， RF パワーを大きくするほど透過率は 向上した. 基板一アンテナ間距離が $5 \mathrm{~cm}$ 以内の場合, 透過率は RF パワーに依存せず， RFパワーが $100 \mathrm{~W} の$ 場合でも，90\%以上の透過率が得られた。ここまでの結 果より，透過率は基板一アンデ間距離に依存し，また 透過率の低い条件では， RF パワー依存性があることが 分かった。

Fig. 8 に基板一アンテナ間距離と製膜速度の関係を示 す. 製膜速度は基板一アンテナ間距離に依存し Fig. 6, すなわち基板一アンテナ間距離と透過率の関係に類似し ていることが分かった．Fig. 9 に製膜速度と透過率の関 係を示す. 製膜速度が比較的遅い領域, すなわち $4 \mathrm{~nm} /$ $\mathrm{s}$ 以下の場合, 透過率は製膜速度に比例し, 製膜速度が 大きいほど, 透過率は向上した. 本研究に抢ける製膜速 度は一般のイオンプレーティング法での值に比較して比 較的小さな值 ${ }^{10)}$ である. 基板一アンテナ間距離を大きく 離すと, すなわち蒸着源にアンテナを近づけると, 蒸着 源であるアルミニウムの表面が窒化しやすく, アルミニ ウムの表面に高融点の窒化アルミニウム層が形成され, 蒸発速度が極端に低下すると予想される.この時蒸着源 からは表面の AlN が昇華モードで蒸発すると予想され る. なた一部蒸発したアルミニウム粒子も基板上ではな

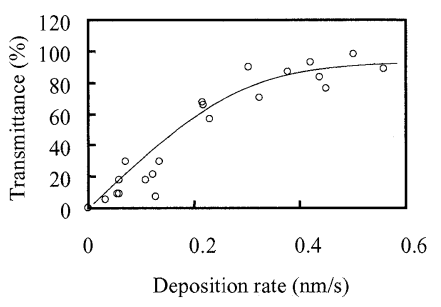

Fig. 9 Dependence of transmittance on deposition rate for AlN thin films.

く蒸発直後に気相上で窒化する割合が増加する．高融点 の AlN の状態で低温の基板に到達する粒子の割合が増 加すると，基板表面での原子の再配列が進まず，結果と して透過率の低下につながったものと思われる。

尚，今回作製した全ての薄膜はX 線回折分析の結果 非晶質であることが分かった。

\section{4. をとめ}

Matrix Method 法により (001) $\mathrm{AlN} / \mathrm{SiO}_{2} /(100) \mathrm{Si}$ 構造 の SAW 特性を計算した。 また，プレーティング法によ り AlN 薄膜を作製し RF アンテナと基板，蒸着源の位 置関係や RFパワーが膜質に与える影響を考察した結 果，次の結論を得た。

(1) 音速は $\mathrm{Si}$ 基板と $\mathrm{AlN}$ の間に $\mathrm{SiO}_{2}$ 層を挿入する ことにより，10〜 $15 \%$ 程度低下（5180 $\rightarrow 4760 \mathrm{~m} / \mathrm{s})$ する が，電気機械結合係数は， $\mathrm{SiO}_{2}$ 層を挿入することによ り，20〜30\%改善 $(0.0050 \rightarrow 0.0075)$ される. また $\mathrm{SiO}_{2}$ の有無にかかわらず電気機械結合係数は水晶の電気機械 結合係数（0.0011）を上回った.

（2）基板一アンテナ間距離が得られた薄膜の透過率に 大きく影響する.

（3）製膜速度は基板一アンテナ間距離に依存してお $\eta$ ，比較的製膜速度の低い領域 $(0.4 \mathrm{~nm} / \mathrm{s}$ 以下) では, 製膜速度が大きくなると透過率は向上した．これは蒸着 源の窒化と大きく関連しているものと予想される.

\section{謝辞}

本研究の一部は，財南海育英会及び山陽放送学術文化 財団の支援を受けなされています。関係各位に感謝いた します。

\section{〔文献〕}

1) K. M. Lakin: Proc. IEEE Ultrasonics Sympo. (2001) p. $827-831$.

2) T. W. Grudkowski: Appl. Phys. Lett. 37, p. 993, 
(1980).

3) T. Shiosaki, T. Yamamoto, T. Oda, K. Hrada and K. Kawabata: Proc. Ultrasonics Symp. (IEEE, New York, 1980) p. 451.

4) J. S. Wang, K. M. Lakin and R. Landin: Proc. 37 th Annu. Frequency Control Symp. (IEEE, New York, 1983) p. 878.

5) H. Okano, T. Tanaka, K. Shibata and S. Nakano: Jap. J. Appl. Phys. 31 (1992) 3017.

6) H. Okano, Y. Takahashi, T. Tanaka, K. Shibata and S. Nakano: Jap. J. Appl. Phys. 31 (1992) 3346.

7) L. Xinjiao, X. Zechuan, H. Ziyou, C. Huazhe, S. Wuda, C. Zhongcai, Z. Feng and W. Ebguang: Thin
Solid Films 139, 361 (1986).

8) T. Tsubouchi and Mikoshiba: IEEE Trans. Sonics Ultrason. SU-32, 634 (1985).

9) F. Hasegawa, T. Takahashi, K. Kubo and Y. Nannichi: Jap. J. Appl. Phys. 26 (1987) 1555.

10) K. Oumi, K. Kashiwagi, H. Kokai and Y. Murayama: Jap. J. Appl. Phys. 40 (2001) L468-70.

11) E. L. Adler: IEEE Trans. Ultrason., Ferroelec., Freq. Contr., 37 (1990) 485.

12) N. Tanaka, Y. Hirao, Y. Kobayashi, H. Okano, T. Usuki, K. Shibata, K. Niki, T. Kameoka and M. Ikeda: Proc.IEEEE Frequency Control Symp. (1998) p. 8790. 